\title{
Correlation between neutrophil-to-lymphocyte ratio and severity scores in septic patients upon hospital admission. A series of 50 patients
}

\author{
DIMITRIOS VELISSARIS*, NIKOLAOS-DIMITRIOS PANTZARIS*, \\ PANAGIOTIS BOUNTOURIS, CHARALAMPOS GOGOS \\ Internal Medicine Department, University Hospital of Patras, Rion, Greece \\ *The authors of this article contributed equally and are listed as first co-authors
}

\begin{abstract}
Introduction. The neutrophil-to-lymphocyte ratio (NLR) as calculated from the white cell differential blood count is a marker that has been used as a prognostic index when assessing patients suffering from several clinical syndromes, including sepsis. The aim of this study was to evaluate the relationship between NLR and the commonly used severity scores of sepsis SOFA, APACHE II and SAPS II in a population of emergency admitted adult patients with sepsis in a tertiary center.

Methods. A prospective observational study was conducted in the Emergency Department of the University Hospital of Patras, Greece, based on data extracted from 50 patients consecutively enrolled, suffering from sepsis of multiple origin. The study period was from May 01, 2017 until June 30,2017 . The NLR was calculated from the total white blood cell (WBC) count values measured from a peripheral venous blood specimen drawn on admission. C-reactive protein (CRP) was also measured. The sepsis severity prognostic scores APACHE II, SAPS II and SOFA were calculated for each patient.

Results. NLR was positively correlated with the sepsis severity prognostic scores on admission (SOFA, $\mathrm{r}_{\mathrm{s}}=0.497, \mathrm{p}<0.001$; APACHE II, $\mathrm{r}_{\mathrm{s}}=0.411, \mathrm{p}=0.003$; SAPS II, $\mathrm{r}_{\mathrm{s}}=0.445, \mathrm{p}=0.001$ ). Total WBC was also significantly correlated with the scores (SOFA, $r_{s}=0.342, p=0.015$; APACHE II, $\mathrm{r}_{\mathrm{s}}=0.384, \mathrm{p}=0.006$; SAPS II, $\mathrm{r}_{\mathrm{s}}=0.287, \mathrm{p}=0.043$ ). Serum CRP did not show any significant correlation either to NLR or to the sepsis severity scores on admission.

Conclusions. NLR is an easily calculated, cost-efficient index that could be used as a tool for clinicians when assessing sepsis patients in the Emergency Department. Although NLR measurement is simple, and rapidly available, future and larger prospective studies are warranted to confirm its definite value as a prognostic index in sepsis patients.
\end{abstract}

Key words: sepsis, neutrophil-to-lymphocyte ratio, APACHE II, SOFA, SAPS II.

\section{INTRODUCTION}

Sepsis and the related multiple organ failure remains a worldwide problem causing high morbidity and mortality rates depending on the studied population [1]. The currently available organ failure scoring systems, such as the Acute Physiology and Chronic Health Evaluation II (APACHE II), the Sequential Organ Failure Assessment (SOFA), and the Simplified Acute Physiology II (SAPS II) scores are useful in the assessment of organ dysfunction over time and have been established as clinically useful indexes of severity and prognosis [2-4]. The neutrophil-to-lymphocyte ratio (NLR), which can be easily calculated from the complete blood count, is an assessable index which has already been used as a prognostic tool in several clinical conditions including sepsis. NLR has received considerable attention and has recently emerged as a potential new biomarker in sepsis, as abnormalities in the immune system pathways consist the corner stone of the pathophysiology of the sepsis syndrome.
In a large study by Hwang et al. published in 2017, including 1395 patients with severe sepsis and septic shock, NLR measured at Emergency Department (ED) admission was independently associated with 28-day mortality [5].

The primary aim of the study was to assess the potential relation of the NLR to the established sepsis calculated prognostic scores in patients with sepsis presenting in the ED. A secondary aim was to evaluate the relation of NLR to the routinely used inflammatory biomarkers $\mathrm{C}$-reactive protein (CRP) and white blood cell (WBC) count in patients with sepsis.

\section{METHODS}

\section{Study population and design}

In this prospective observational study, we consecutively enrolled fifty adult patients with sepsis of several origins. The study was conducted 
in the ED of the University Hospital of Patras, Western Greece, from May 01, 2017 to June 30, 2017. The University Hospital of Patras Research and Ethics Committee approved the study protocol. Written consent for participation in the study was obtained from all enrolled patients, and if that was not feasible a designated family member consented. All data were stored in an electronic database in a secure, locked computer. The participated research team included Consultants and resident physicians. After initial assessment in the ED all enrolled patients were finally admitted to the Internal Medicine Department of the Hospital for further treatment.

\section{Data collection}

Initial assessment of patients in the ED included a completion of a form with the past medical history and the current clinical status combined to physical examination findings, laboratory tests and radiological imaging studies for each patient according to the clinical suspicion for the possible source of sepsis. Venous blood samples were obtained by drawing ten milliliters of blood from each patient. Complete blood count and a biochemical analysis were then performed. Samples for cultures were sent from every suspected for infection biological fluid. The NLR was computed from the complete blood count. Serum CRP levels were measured by rate nephelometry. For each patient, the sepsis severity scores SOFA, APACHE II, and SAPS II were calculated on admission.

For the inclusion, we used the quickSOFA criteria, which were more suitable for the emergency department evaluation (Sepsis-3) [6]. We included all consecutive patients who fulfilled at least two of the three quickSOFA criteria (respiratory rate $\geq 22$, altered cognition, systolic blood pressure $\leq 100 \mathrm{mmHg}$ ) at the emergency room, and in which infection as a cause of the disease was subsequently demonstrated. Exclusion criteria for the study population were the use of antibiotics for more than 24 hours at the time of admission, conditions known to affect total and differential WBC counts such as treatment with steroids and medications proven to affect WBC, hematologic disorders, chronic inflammatory conditions, history of steroid use within 3 months prior to admission, and history of chemotherapy or radiotherapy within the previous 4 weeks.

\section{Statistical analysis}

Data were analyzed using descriptive statistical measurements, including frequencies for discrete variables or means, standard deviations, medians and interquartile ranges for continuous variables. Normality was checked with the one sample ChiSquare test for ordinal variables and with the one sample Kolmogorov-Smirnov test for continuous variables. Though serum CRP had a normal distribution, the rest of the variables did not. The sample size was also relatively small, so the analysis was conducted by using non-parametric tests. Data analysis included a bivariate correlation analysis using Spearman's $r_{s}$ coefficient in search for significant correlations between NLR, serum CRP, age, and the sepsis severity scores (SOFA, APACHE II and SAPS II). The significance level was set at a p-value of 0.05 . All data analysis was conducted using the IBM SPSS Statistics version 23.0 software package.

\section{RESULTS}

\section{Patient data and demographics}

Minimum patient age was 30 and maximum age was 92 years (mean 68.4 years St.d 16.5 years). Twenty-eight patients were male $(56 \%)$. Mean patient age was $68.4 \pm 16.5$ years $(\min 30$; $\max 92)$. Descriptive statistics along with the statistical data from the SOFA, APACHE II and SAPS II prognostic scores are presented in Table 1. The final ED diagnosis for each patient is presented in Table 2 .

Table 1

Descriptive Statistical Data

\begin{tabular}{lcccc}
\hline Variables & Minimum & Maximum & Median & $\begin{array}{c}\text { Interquartile } \\
\text { range }\end{array}$ \\
NLR & 2.37 & 56.12 & 11.1 & 12.75 \\
WBC count & 3,890 & 37,930 & 15,620 & 9,020 \\
Serum CRP & 0.9 & 41.2 & 14.1 & 14.4 \\
SOFA & 2 & 10 & 3 & 4 \\
APACHE II & 1 & 26 & 12 & 8 \\
SAPS II & 7 & 73 & 36.5 & 20.8 \\
\hline
\end{tabular}

Table 2

Final Emergency Department Diagnosis

\begin{tabular}{lc}
\hline Diagnosis & Cases \\
Chest infection & $25(50 \%)$ \\
Primary bacteremia & $5(10 \%)$ \\
Cellulitis & $1(2 \%)$ \\
Cholecystitis & $4(8 \%)$ \\
Urinary tract infection & $8(16 \%)$ \\
Meningitis & $4(8 \%)$ \\
Peritonitis & $3(6 \%)$ \\
Total & $50(100 \%)$ \\
\hline
\end{tabular}

\section{Bivariate correlation analysis}

Based on the bivariate correlation analysis using Spearman's $r_{s}$ coefficient, we found that NLR was positively correlated with the sepsis severity 
prognostic scores on admission (SOFA, $\mathrm{r}_{\mathrm{s}}=0.497$, $\mathrm{p}<0.001 ;$ APACHE II, $\mathrm{r}_{\mathrm{s}}=0.411, \mathrm{p}=0.003$; SAPS II, $\left.r_{s}=0.445, p=0.001\right)$. NLR also showed a significant correlation with total WBC count $\left(\mathrm{r}_{\mathrm{s}}=\right.$ $0.531, \mathrm{p}<0.001)$. Total WBC count was also positively correlated with the three scores (SOFA, $\mathrm{r}_{\mathrm{s}}=0.342, \mathrm{p}=0.015$; APACHE II, $\mathrm{r}_{\mathrm{s}}=0.384, \mathrm{p}=$ 0.006; SAPS II, $r_{s}=0.287, p=0.043$ ).

Age also showed a statistically significant positive correlation with the scores (SOFA, $\mathrm{r}_{\mathrm{s}}=$ $0.501, \mathrm{p}<0.001$; APACHE II, $\mathrm{r}_{\mathrm{s}}=0.617, \mathrm{p}<0.001$; SAPS II, $\left.r_{s}=0.646, p<0.001\right)$, but it was not associated with a greater NLR $\left(r_{s}=0.123, p=\right.$ 0.393). Serum CRP did not show any significant correlation with either NLR $\left(r_{s}=0.133, p=0.356\right)$ or the sepsis severity scores on admission (SOFA, $\mathrm{r}_{\mathrm{s}}=0.021, \mathrm{p}=0.886$; APACHE II, $\mathrm{r}_{\mathrm{s}}=0.009, \mathrm{p}=$ 0.536 ; SAPS II, $r_{s}=-0.077, p=0.596$ ).

\section{DISCUSSION}

Plenty of biomarkers, such as cytokines and acute phase proteins, have been used in the assessment of patients suspected with sepsis in both clinical practice, and for research purposes [7-9]. Additionally, a number of disease severity scores have been developed for patients who are presented in the ED and are finally hospitalized with a suspected infection, aiming to help clinicians in sepsis recognition as well as in risk stratification $[10,11]$. Three organ failure scoring systems, currently used in everyday clinical practice, the APACHE II, SOFA and SAPS II scores, have been established as useful indexes of severity and prognosis $[4,12,13]$.

Part of the validated criteria for the definition of systemic inflammatory response syndrome (SIRS) is an abnormal white blood cell count $(>12,000 / \mu \mathrm{L}$ or $<4,000 / \mu \mathrm{L}$ or $>10 \%$ immature forms). The sepsis syndrome is also characterized by several dysfunctions at the cellular level. These include alterations in the total number, and the function of several WBC types with either excessive activation or depressed function. The neutrophil is the key cellular component of the human host defense system against an infection and its depressed function during the sepsis syndrome is characterized by their failure to phagocytize and clear the invading pathogens. A persistently increased number of neutrophils is an alert sign for clinicians that the source of infection might not be eradicated [14, 15]. Lymphocytes are also involved in the pathogenesis of the sepsis syndrome. The subsequent dysregulated host response to infection leads to various alterations, not only in the number of the total circulating lymphocytes, but also in the different T-cell subpopulations [16]. Lymphocyte apoptosis is also rapidly increased in the blood of septic shock patients and it leads to a profound lymphopenia that persists and is associated with a poor outcome [17]. In 2001, Zahorec et al. showed a positive correlation between the severity of the disease in critically ill patients and the grade of neutrophilia and lymphocytopenia [18].

The NLR, calculated from the complete blood count, is an easily calculated index, seeming to represent an underlying inflammatory process and it has been associated with mortality in various critically ill populations. Several data highlight the relation of elevated NLR and worse outcomes in oncology patients $[19,20]$, while others emphasize the correlation of an increased NLR to worst outcomes and adverse effects in specific clinical conditions such as acute coronary syndromes or acute pancreatitis $[21,22]$.

The role of the NLR as a prognostic factor in sepsis is a debate, as there are currently not many data in the medical literature, investigating its potential uses. In a prospective observational study by Liu et al. after assessing 333 patients with sepsis upon intensive care unit (ICU) admission, increased NLR levels were associated with a poor outcome [23]. Higher NLR values were also correlated with the severity of sepsis in adult patients with community acquired pneumonia and E. coli infections [24, 25]. In the study by Salciccioli et al., critically ill ICU patients were assessed. The subgroup of patients with sepsis had statistically significant higher NLR values upon ICU admission than those without sepsis. Nevertheless NLR levels in those patients had no significant correlation with the final outcome (28-day mortality) [26].

In our study we demonstrated a weak but statistically significant relationship between the NLR and the sepsis prognostic scores SOFA, APACHE II and SAPS II upon ED presentation. Our results seem to be partially in accordance to those by Hwang et al. [5]. The serum CRP values in our series of patients failed to significantly correlate to the sepsis severity scores on admission.

Nonetheless some limitations should be taken into consideration for this study. This is a single center observational study with a small sample size of sepsis patients. We applied strict exclusion criteria in order to avoid the enrollment of patients with abnormal baseline WBC counts. This resulted in the exclusion of patients with several serious comorbidities that could have affected our results. All 
the enrolled patients had a positive outcome and were discharged from the hospital. Also, we calculated the NLR without further analyzing the different subtypes of lymphocytes. Finally, we compared the NLR only to the routinely used biomarkers WBC and CRP and not to other sepsis biomarkers used in more financially advanced ED settings (e.g. procalcitonin, IL6).

\section{CONCLUSIONS}

The NLR is a biomarker easy to integrate in everyday clinical practice, as it is cost effective and easily calculated. The NLR could be a promising tool in the initial assessment of patients with sepsis as we found a weak but significant correlation between NLR and the commonly used scores of severity and prognosis of sepsis. Emergency Department physicians should always bear in mind the complexity of the clinical entity of sepsis and that none single biomarker can substitute the systematic approach needed in the assessment of the septic patient. Future prospective clinical research and multicenter studies are warranted to confirm our findings.

Conflict of Interest: This work was supported solely by Department funds. All authors state that they do not have any conflicts of interest to report.

Introducere. Raportul neutrofile/limfocite (NLR) este calculat din hemogramă şi este un marker prognostic al pacienților cu diferite patologii, incluzând sepsisul. Scopul studiului a fost de a evalua relația dintre NLR şi scorurile de severitate SOFA, APACHE II şi SAPS II în cadrul camerei de urgență al unui centru terțiar.

Materiale şi metode. A fost realizat un studiu observațional în cadrul departamentului de primiri urgențe a Spitalului Universitar Patras din Grecia. Au fost incluşi 50 de pacienți consecutiv diagnosticați cu sepsis. Perioada studiului a fost din 1 mai 2017 până în 30 iunie 2017. NLR a fost calculat pe baza hemogramei prelevate în momentul internării. Au fost măsurate şi nivelurile proteinei $C$ reactive (CRP). Pentru fiecare pacient au fost calculate scorurile de severitate APACHE II, SAPS II şi SOFA.

Rezultate. NLR s-a corelat pozitiv cu scorurile de severitate (SOFA, $r=0.497$, $p<0.001$; APACHE II, $r=0.411, p=0.003$; SAPS II, $r=0.287, p=0.043$ ). Nivelurile serice ale CRP nu s-au corelat nici cu NLR nici cu scorurile de severitate.

Concluzii. NLR este un instrument usor de calculat, cost-eficient ce poate fi folosit de către clinicieni în camera de gardă atunci când sunt în fața unui pacient cu sepsis. Deşi măsurarea NLR este uşoară şi rapidă, viitoare studii prospective sunt necesare pentru a defini valorea acestuia ca index prognostic la pacienții cu sepsis.

Correspondence to: Dimitrios Velissaris MD, PhD, Assistant Professor,

Internal Medicine Department, University Hospital of Patras, Rion, Greece

mobile: +306974909988 tel: +302610999587

E-mail: dvelissaris@upatras.gr

\section{REFERENCES}

1. STEVENSON EK, RUBENSTEIN AR, RADIN GT, WIENER RS, WALKEY AJ. Two decades of mortality trends among patients with severe sepsis: a comparative meta-analysis*. Crit Care Med 2014; 42: 625-31.

2. KNAUS WA, DRAPER EA, WAGNER DP, ZIMMERMAN JE. APACHE II: a severity of disease classification system. Crit Care Med 1985; 13: 818-29.

3. VINCENT JL, MORENO R, TAKALA J, et al. The SOFA (Sepsis-related Organ Failure Assessment) score to describe organ dysfunction/failure. On behalf of the Working Group on Sepsis-Related Problems of the European Society of Intensive Care Medicine. Intensive Care Med 1996; 22: 707-10.

4. LE GALL JR, LEMESHOW S, SAULNIER F. A new Simplified Acute Physiology Score (SAPS II) based on a European/North American multicenter study. JAMA 270: 2957-63.

5. HWANG SY, SHIN TG, JO IJ, et al. Neutrophil-to-lymphocyte ratio as a prognostic marker in critically-ill septic patients. Am J Emerg Med 2017; 35: 234-9. 
6. SINGER M, DEUTSCHMAN CS, SEYMOUR CW, et al. The Third International Consensus Definitions for Sepsis and Septic Shock (Sepsis-3). JAMA 2016; 315: 801-10.

7. PIERRAKOS C, VINCENT J-L. Sepsis biomarkers: a review. Crit Care 2010; 14: R15.

8. MARSHALL JC, REINHART K, INTERNATIONAL SEPSIS FORUM. Biomarkers of sepsis. Crit Care Med 2009; 37: $2290-8$.

9. SCHUETZ P, CHRIST-CRAIN M, MÜLLER B. Biomarkers to improve diagnostic and prognostic accuracy in systemic infections. Curr Opin Crit Care 2007; 13: 578-85.

10. BONE RC, FISHER CJ, CLEMMER TP, SLOTMAN GJ, METZ CA, BALK RA. Sepsis syndrome: a valid clinical entity. Methylprednisolone Severe Sepsis Study Group. Crit Care Med 1989; 17: 389-93.

11. HOWELL MD, TALMOR D, SCHUETZ P, HUNZIKER S, JONES AE, SHAPIRO NI. Proof of principle: the predisposition, infection, response, organ failure sepsis staging system. Crit Care Med 2011; 39: 322-7.

12. GUIRGIS FW, PUSKARICH MA, SMOTHERMAN C, et al. Development of a Simple Sequential Organ Failure Assessment Score for Risk Assessment of Emergency Department Patients With Sepsis. J Intensive Care Med 2017: 885066617741284.

13. DESAI S, LAKHANI JD. Utility of SOFA and APACHE II score in sepsis in rural set up MICU. J Assoc Physicians India 2013; 61: 608-11.

14. FUNG YL, FRASER JF, WOOD P, MINCHINTON RM, SILLIMAN CC. The systemic inflammatory response syndrome induces functional changes and relative hyporesponsiveness in neutrophils. J Crit Care 2008; 23: 542-9.

15. NIERHAUS A, KLATTE S, LINSSEN J, et al. Revisiting the white blood cell count: immature granulocytes count as a diagnostic marker to discriminate between SIRS and sepsis - a prospective, observational study. BMC Immunol $2013 ; 14: 8$.

16. DAHN MS, WHITCOMB MP, LANGE MP, JACOBS LA. Altered T-lymphocyte subsets in severe sepsis. Am Surg 1988; 54: 450-5.

17. LE TULZO Y, PANGAULT C, GACOUIN A, et al. Early circulating lymphocyte apoptosis in human septic shock is associated with poor outcome. Shock 2002; 18: 487-94.

18. ZAHOREC R. Ratio of neutrophil to lymphocyte counts--rapid and simple parameter of systemic inflammation and stress in critically ill. Bratisl Lek Listy 2001; 102: 5-14.

19. AZAB B, BHATT VR, PHOOKAN J, et al. Usefulness of the neutrophil-to-lymphocyte ratio in predicting short-and long-term mortality in breast cancer patients. Ann Surg Oncol 2012; 19: 217-24.

20. WALSH SR, COOK EJ, GOULDER F, JUSTIN TA, KEELING NJ. Neutrophil-lymphocyte ratio as a prognostic factor in colorectal cancer. J Surg Oncol 2005; 91: 181-4.

21. MUHMMED SULIMAN MAR, BAHNACY JUMA AA, ALI ALMADHANI AA, PATHARE AV, ALKINDI SSA, UWE WERNER F. Predictive Value of Neutrophil to Lymphocyte Ratio in Outcomes of Patients with Acute Coronary Syndrome. Arch Med Res 2010; 41: 618-22.

22. AZAB B, JAGLALL N, ATALLAH JP, et al. Neutrophil-lymphocyte ratio as a predictor of adverse outcomes of acute pancreatitis. Pancreatology 2011; 11: 445-52.

23. LIU X, SHEN Y, WANG H, GE Q, FEI A, PAN S. Prognostic Significance of Neutrophil-to-Lymphocyte Ratio in Patients with Sepsis: A Prospective Observational Study. Mediators Inflamm 2016; 2016: 1-8.

24. DE JAGER CPC, WEVER PC, GEMEN EFA, et al. The neutrophil-lymphocyte count ratio in patients with communityacquired pneumonia. PLoS One 2012; 7: e46561.

25. LJUNGSTROM L, JACOBSSON G, ANDERSSON R. Neutrophil-lymphocyte count ratio as a biomarker of severe sepsis in Escherichia coli infections in adults. Crit Care 2013; 17: P25.

26. SALCICCIOLI JD, MARSHALL DC, PIMENTEL MAF, et al. The association between the neutrophil-to-lymphocyte ratio and mortality in critical illness: an observational cohort study. Crit Care 2015; 19: 13.

Received December 28, 2017 